\title{
Role of Social Media Community in Strengthening Trust and Loyalty for a University
}

\author{
Raziye NEVZAT, Yilmaz AMCA, Cem TANOVA, Hasan AMCA
}

\begin{abstract}
As the increasing internationalization of higher education creates competition among the universities, many institutions are making use of social media communities to attract and retain students. We surveyed 215 users of the Eastern Mediterranean University (EMU) Facebook page to investigate how it influences their identification with the university community and the university brand. We further investigate how this identification influences the trust and loyalty to the institution and leads to positive behaviors such as promoting the university to their peers as an active member of the university community. Our results show that the perceived strength of the Facebook community is related to the identification with the university community and the university brand which in turn are related to trust and loyalty. Higher loyalty is linked to citizenship behaviors such as increased contribution to the educational process labeled in-role behaviors and providing positive word of mouth about the university labeled extra-role behaviors. With the challenges of a diverse and global student body which is expected to continue increasing, universities can benefit from use of social media in developing identity, loyalty and trust.
\end{abstract}

\section{Introduction}

The number of students enrolled in higher education institutions outside their home country increased drastically by an average factor of $96.75 \%$ between 2000 and 2009. In the year 2008, the 13 countries that send a large number of students abroad had nearly 1 Million students enrolled in the global higher education system (Becker \& Kolster, 2012). The increasing trend in the international student mobility continues with an increasing acceleration. The number of international students, which was 2.7 Million in 2004 and 4.0 Million in 2016 is predicted to be 4.9 Million in 2025 (Varghese, 2008). To adjust to the growing needs for higher education, some countries invest on opening new institutions while others send their students abroad. Following this trend in higher education, the number of higher education institutions now increased to 23,729 at the beginning of 2016 ("Webometrics: Ranking Web of Universities," 2016). The increasing internationalization and rapid growth of the higher education institutions require these institutions to find ways to differentiate themselves from the others and to communicate their unique traits to their stakeholders such as students, alumni, employers, and the academic community. Branding in higher education can help the institution to become more memorable and distinguishable from the others. McAlexander, Koenig, and Schouten (2005) argue that a university is a brand community 
where the stakeholders interact with each other and also with the university which is the owner and steward of the brand. University administrations are in a place to shape the brand community with their involvement and their decisions. The social media can serve as a critical tool in enforcing the university brand (Alkhas, 2011).

In addition to internationalization, another significant change in higher education is the entry of the digital natives. The group of 18-29-year-old internet users who were born into the internet world is referred to as digital natives (Jones, Ramanau, Cross, \& Healing, 2010) whereas the previous generations are considered to be digital immigrants (Prensky, 2001). Prensky (2005) indicates that these consumers will require to be connected in all aspects throughout their lives. In 2008, these digital natives were reported to spend more than eight hours a day in digital technology whereas this number has increased to twelve in 2015 (J. J. Arnett, 2015; Lin, 2008). Since current and prospective university students are considered to be digital natives, it is crucial to see how they form brand trust and brand loyalty towards higher education institutions.

As internationalization of Higher Education (HE) continues, the increasing competitive pressures on the universities and other Higher Education Institutions (HEI) forces them not only to develop more effective promotional methods but also to employ more efficient integrated marketing strategies for building and maintaining a coordinated and customer oriented marketing strategy which addresses larger geographical areas (Judson, Aurand, Gorchels, \& Gordon, 2008). Building a strong university brand community in social media is necessary not only for attracting the target people to the university but also for retaining them and maintaining their loyalty and positive word of mouth after they complete their education. Social media in higher education institutions can enhance the student experience, alumni communication, and brand development. It is also a tool that can enhance identification with the university and can assist in increasing student engagement. When we take the needs and expectations of the digital natives who are the new entrants to higher education institutions, we can further appreciate the relevance of social media for higher education.

Members of an effective university brand community could be expected to develop more positive attitudes and behaviors towards the university. These behaviors could include making donations to the institution and purchase of university merchandise (McAlexander, Koenig, \& Padilla, 2006) and also enrolling in the academic programs of the university, providing positive word of mouth, developing positive view of the graduates of the university. Brand community consists of all the people for whom the brand is relevant and includes the relationships among them in their use of the brand (McAlexander, Koenig, \& Schouten, 2005).

Recent research has focused on the impact of social media on brand trust and brand loyalty. Laroche, Habibi, \& Richard (2013) has utilized brand community, brand trust and loyalty literatures to show how social media influences the customer centric model elements such as relationships among focal customers and brand, brand loyalty, product, company and other customers. Ho (2015) has demonstrated that a company's brand community on Facebook increases the customer identification with the brand community and the brand itself in a study of service oriented firms and their customers in Taiwan. However, the role of brand trust and brand loyalty in higher education institutions have not been thoroughly investigated.

In this study, we measure how the strength of the Facebook community of the university influences the students' and potential students' identification with the university community which in turn 
influences the students' identification with the university. The identification with the university and the university community will be related to improved university brand trust and loyalty which will result in organizational citizenship behaviors of the students which are classified as in role and extra role behaviors. The in-role behaviors help to improve the educational experience and engagement whereas extra-role behaviors assist in recruiting new students through positive word of mouth.

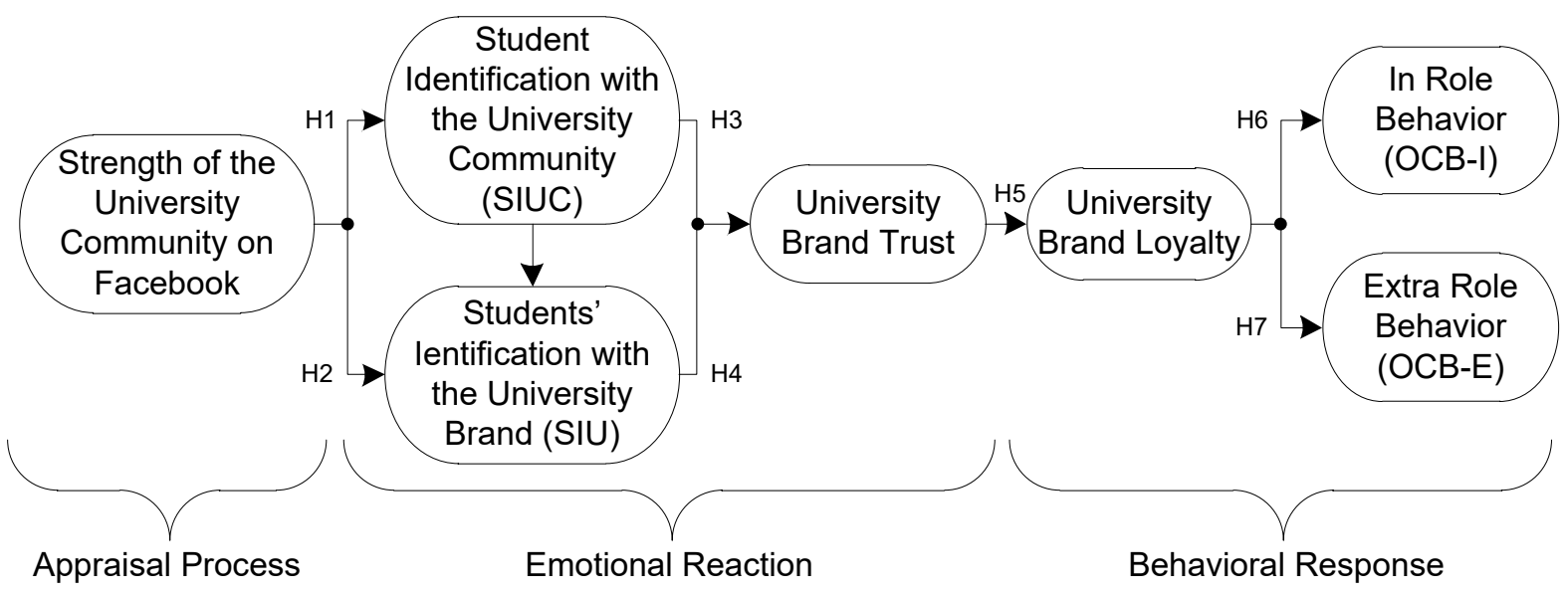

Figure 1: Conceptual Model

\section{Theoretical Framework and Hypotheses Development}

We use the attitude theory as described by Bagozzi (1992) which states that there is a distinct sequence that begins with an appraisal process that results in an emotional reaction leading to the behavioral response. In Bagozzi's (1992) reformulation of the attitude theory, in the first stage the individual evaluates or appraises the past, present and future outcomes (Bagozzi, Gopinath, \& Nyer, 1999). In other words, they make an evaluative judgment about an event or an incident that they are involved in or some object, person or entity that has personal meaning for them. The focus is the subjective interpretation not the objective event or the circumstance because different individuals may appraise the same outcome differently. Based on the appraisal, the next stage is the emotional reaction. Particular emotions result from the appraisal. For example, an individual may be pleased with the performance of a product or the experience of a service or conversely may get angry due to a promise that is not kept. A fan may feel pride in their team's achievement.

We believe that the members of the Facebook community for the university will appraise the emotional and rational benefits that they receive from being associated with the community and the university. This assessment will result in an emotional reaction which will determine to what extent the user will identify with the university community and the university brand. This will also 
influence the feelings of trust. The loyalty as well as in-role and extra-role behaviors will result from this emotional or affective response.

Our proposed model is also supported by the social exchange relationship between the university and the stakeholders. According to the Social Exchange Theory people seek to reciprocate the positive benefits that they perceive to receive (Bateman \& Organ, 1983). The theory argues that the individual will feel obliged to give back when they receive. Bateman \& Organ (1983) have used this theoretical argument to develop the concept of Organizational Citizenship Behaviors (OCB) and argued that as job satisfaction of employees increase, they reciprocate by demonstrating more "citizenship behaviors" such as altruistic, helping, and compliance even when there is no direct supervision.

The exchanges are not just on an economic basis, but the social exchange refers to the building of lasting relationships over time instead of focusing on quick transactions which maintain the balance. The individuals may reciprocate through citizenship behaviors such as going out of their way to help others, providing positive word of mouth or performing additional tasks without the expectation of direct rewards.

Rosenbaum and Massiah (2007) extend the concept of "citizenship behaviors" to include customers. When customers feel that the organization is providing care and attention to their needs, they will reciprocate by voluntarily providing support for the organization. Furthermore, customers who receive social emotional support and instrumental support from other customers will feel obliged to help out other customers without in response. This voluntary support is not just directed to the specific customers who provided help but will include others.

\subsection{The relationship between Facebook community membership and identification with the university community and the university brand}

Social identity theory refers to identification as a perception of oneness with a group of persons (Ashforth \& Mael, 1989a). People go beyond their personal identity or their sense of self and develop a social identity with the group. In the marketing context, consumers identify and associate themselves with brands that echo and strengthen their self-identities (Ahearne, Bhattacharya, \& Gruen, 2005; Ashforth \& Mael, 1989b). Individuals have several identities which shapes how they define themselves or their self-conception. However, according to the identity theory theses identities are arranged in a hierarchical order where salient or prominent identities are more influential on their behaviors (D. B. Arnett, German, \& Hunt, 2003).

There is an affective and a cognitive component to social identity (Bergami \& Bagozzi, 2000). When members of the brand community in social media identify themselves with the group based on an assessment of how similar they are to the other members and how dissimilar they are to the nonmembers this is considered a cognitive component of identification. The extent to which identification is based on the emotional engagement with the group such as sharing the pride or sorrow, is considered the affective component (Algesheimer, Dholakia, \& Herrmann, 2005).

Brand community is a network of associations that connect the customers to a brand and via the brand, the products, services, the institution and the other customers (McAlexander et al., 2006). The concept of brand community is especially appropriate for universities since the university 
provides a wide range of services and products under its brand. In a study among university students in the USA the students reported that the use of social networking tools with the university brand makes them feel more connected to their university (CCCSE, 2009). The same study also revealed that the use of social media technology for academic purposes was related to the level of engagement of the students.

The students find it more convenient to use social media technology to stay connected. For example, Eastern Mediterranean University uses social media technology including Twitter, Facebook, Instagram and Periscope in order to increase the engagement of the students with the university. Students often prefer to communicate their concerns or questions via Facebook Messenger since they have a perception that responses to e-mail queries are slower where shorter messages receive an almost instant response. In order to strengthen the university community, the university maintains a variety of branded Facebook pages in order to link the faculty, current students, alumni, prospective students and others who wish to be kept in touch with the institution. Scott and Lane (2000) state that people do not need to be the members of the organization to feel identified. Therefore although, in using social media, university's foremost aim is to create a community identity with its members, it can do so with the non-members if the community identification is high on its social media accounts.

Hypothesis 1: Strength of the University Facebook community is related to the level of identification with the university community

Hypothesis 2: Strength of the University Facebook community is related to the level of identification with the university brand

\subsection{The relationship between university community and university brand identification and} university brand trust

Halbesleben and Wheeler (2009) argue that students may identify their relationship with the university using the metaphor of customers, as employees, as co-producers, or as junior partners. The students as a customer metaphor has gained popularity as the universities attempted to become more student centered and more responsive to their needs in line with the teachings of the Total Quality Management movement. In the student as employee metaphor, the university regards the student as a subordinate and the faculty members as their supervisors where the student is expected to perform tasks assigned by the faculty member acting like a manager. In the student as co-producer model, instead of regarding the students as customers whose needs and desires should be satisfied, the university's role is to provide them with the resources so they can produce the learning that is necessary along with the university staff and faculty. The student as junior partner model sees the student as a partner to the faculty members however there is also a hierarchy that provides higher status to the faculty.

Halbesleben and Wheeler (2009) demonstrate that when students identify with the university as co-producers instead of customers, they were more satisfied and more likely to donate to the university after graduation. When the university uses the social media in an interactive way, this 
can enable the students to identify more with the university as co-producers instead of merely as customers. The nature of the social media will allow the students not only to consume information, but also to have a role in which pieces of information is shared more widely and also to comment or post new information. This in turn will help them to identify themselves more as co-producers and thus feel more trust and loyalty to the university.

When the level of identification with the brand community is high, the customers are more supportive and they are more likely to make positive brand recommendations (Algesheimer et al., 2005). The reason that identification leads to positive brand recommendations may be because when individuals identify themselves with a well-regarded brand, they form positive attitudes toward the brand and the positive attitudes result in the behavior that is in line with the positive attitudes (Bergami \& Bagozzi, 2000). In this case when a student identifies himself/herself with the university brand, they will develop higher levels of trust towards that brand. Another explanation for the identification - trust relationship is based on the information asymmetry where the customer is not in a position to fully understand the many details of what makes the product or service better in terms of quality, they rely on the brand to simplify their choice. In terms of higher education, the universities have an intangible and complex offering which requires a brand to help the stakeholders in their decision making processes regarding the university (Judson et al., 2008). The university brand needs to describe the university and represent the value that it provides using a clear and persuasive explanation to allow individuals to understand this value with the limited amount of information that they have (Judson et al., 2008). When used effectively, social media presence and the brand community of the university will aid the contacts and relationships between the various stakeholders of the university. In addition the information sharing and dissemination via social media will reduce the information asymmetry and decrease uncertainty and lead to greater predictability which results in higher brand trust (Laroche et al., 2013).

Hypothesis 3: Identification with the university community is related to the level of university brand trust

Hypothesis 4: Identification with the university brand is related to the level of university brand trust

\subsection{The relationship between university brand trust and university loyalty}

A major antecedent of loyalty is trust (Chaudhuri \& Holbrook, 2001; Delgado-Ballester \& Luis Munuera-Alemán, 2001; Laroche et al., 2013). Previous research demonstrated that brand communities in social media enhance brand loyalty and trust mediates this relationship. In other words, the strength of the online brand community will enhance brand trust which in turn will lead to higher levels of loyalty (Laroche et al., 2013). A strong consumer brand will attract the targeted customer groups and correspondingly an effective university brand will enable the university to compete for the best students and faculty members, increase alumni loyalty and contributions, and improve community support (Judson et al., 2008). 
With the shift of emphasis in academic literature and practice towards relationship marketing, more attention has been directed towards understanding how trust serves as an antecedent of loyalty. Much of the research had focused on brand reputation and satisfaction leading to loyalty, however, the current discussion of trust views the brand as the consumer's partner in a long term relationship. It has been shown that trust leads to higher commitment especially when the customer involvement is high. The customer commitment towards the brand also brings higher price tolerance (Delgado-Ballester \& Luis Munuera-Alemán, 2001).

Laroche, Habibi, Richard, \& Sankaranarayanan (2012) found that social media brand communities enhance the bond among the members and create a feeling of community which creates value for the members as well as for the company. They also show that social media brand communities lead to increased brand loyalty through the development of brand trust as a mediator.

Hypothesis 5: University brand trust is related to the level of university loyalty

\subsection{Citizenship Behaviors}

Organizational Citizenship Behaviors were initially defined as "individual behavior that in the aggregate aids organizational effectiveness, but that is neither a requirement of the individual's job nor directly rewarded by the formal system" (Bateman \& Organ, 1983). However, this definition was criticized for focusing too much on the extra role nature of the behaviors. Organizational Citizenship Behaviors can be viewed on a continuum ranging from in-role behaviors such as respect for work and following the rules and procedures voluntarily to extra-role behaviors such as devoting more time and effort to tasks that will help the organization without any expectation of rewards (Vey \& Campbell, 2004). In the marketing literature the concept of Organizational Citizenship Behaviors has been adapted to the Customer Citizenship Behavior (Rosenbaum \& Massiah, 2007).

During the service encounter the customer plays an active role to such an extent that they have been called "partial employees" due to the significance of their participation in the service creation process (Bove, Pervan, Beatty, \& Shiu, 2009). In these settings the quality of the experience also depends on the knowledge and skills of the participant. This participation is through in role and extra role behaviors. The behaviors that facilitate the effectiveness of the service delivery are called the in-role behaviors. Examples may be being on time for an appointment, providing accurate information and constructive feedback, and fulfilling obligations.

The behaviors that go beyond facilitating the effectiveness of the current service received such as voluntary behaviors to help the organization are labeled extra-role behaviors. These positive behaviors bay be directed towards the organization, the personnel or towards other customers. Examples may be giving thank you notes to the staff for excellent service, providing positive word of mouth about the organization and its service quality (Bove et al., 2009).

In-role behaviors can be considered customer co-production behaviors. Especially in education the students can be viewed as co-producers instead of customers. Co-production behaviors are crucial in some settings for effective service delivery. Some of the research on co-production role of customers have involved the self-service stations in retail or use of ATM machines or online banking systems for financial institution customers. Much of the research focused on the issue of 
cost reduction by the use of co-production behaviors, however in educational institutions it goes beyond cost reduction. A further criticism of the existing studies is that most of the research on coproduction behaviors has been theoretical, and lacked focus (Groth, 2005). Students are coproducers in the university. They need to be active participants in the learning process and they need to act as co-producers by conducting research, participating in groups, providing feedback and even contributing to the decision making in the university.

Hypothesis 6: University loyalty is related to the level of in role behaviors

Hypothesis 7: University loyalty is related to the level of extra role behaviors

\section{Research Method and data}

\subsection{Sample and Measures}

Our sample was chosen from the users of the Facebook page of the Eastern Mediterranean University located in North Cyprus. The university has a large number of international students and uses social media in as part of their integrated marketing strategy. The number of students in North Cyprus, which become a significant destination for international students over the last decade, rose from 40,000 to more than 70,000 in 10 years. Only 15\% of these are local students from North Cyprus, thus a very large majority of the university students are international. Considering that the total population in North Cyprus is 286,000 (as of 2011), this shows the significance of the university students to all aspects of life in the country. With such a diverse student body and alumni who live and work in many different countries around the world, an effective method of establishing and maintaining identification with and loyalty to the university is needed.

We intended to measure how the strength of the Facebook community of the university influences the current students' and potential students' identification with the university community which in turn influences the students' identification with the university brand. We expect that identification will be related to improved university brand trust and loyalty which will result in organizational citizenship behaviors of the students and potential students. Thus target sample was users of the university Facebook page and our data were collected using an online survey posted on the university official Facebook page. Out of the total 146,000 users that have "liked" the page we had 250 responses. We had to remove responses that had too many missing data. Of the 211 useable responses, $158(75.2 \%)$ were male while $52(24.8 \%)$ were female. With regards to age, 131 (74.0\%) were 20-30 years old, this accounting for the largest proportion of the sample. 35 (19.8\%) were under 20, followed by $11(5.6 \%)$ who were between $31-40$ years. The majority of the respondents had been members of the brand community 79 (39.9\%) for 1-2 years, 66 (33.3\%) 2 years or above, and $53(26.8 \%)$ for less than one year. $28(14.1 \%)$ were postgraduate students and $170(85.9 \%)$ were undergraduate students. Finally, of 211 respondents, 91 have a CGPA lower than 2.5, 84 have a CGPA between 2.5-3.5 and 36 have a CGPA higher than 3.5.

To develop our measures, we investigated the theoretical and empirical literature and we found existing measurement scales that have been validated by previous studies. We made some changes 
to the scales in order to make them appropriate for our study context. The Strength of the University Community on Facebook (UCF) measures the degree to which members of the university Facebook page feel bond to each other, share information and experience, and the extent to which they find these exchanges useful. Three items were adopted from (Ho, 2015; Laroche et al., 2013) developed by Srinivasan, Anderson, \& Ponnavolu (2002) . Cronbach alpha reported in the literature ranged from 0.66 (Laroche et al., 2013) to 0.77 (Ho, 2015). The Student Identification with the university community measures how much the participants identified themselves with the rest of the university community. Sample items such as "if this community planned something, I would think it as something "we" would do rather than something "they" would do" targeted to assess the salience of their association with the university with regard to their self-concept. Total of three items were adapted from previous studies (Algesheimer et al., 2005; Bergami \& Bagozzi, 2000; Ho, 2015) and had Cronbach alpha values reported in the literature ranged from .80 - .94. Student identification with the university brand was made up of three items adapted from Ho (2015). Items such as "when someone criticizes the university, it feels like a personal insult" were used to measure the level of association with the university brand in general (instead of focusing on the community in particular).

Brand trust and brand loyalty items were adapted from the scale used by Laroche et al., (2013) and developed by Srinivasan et al., (2002). There were three items measuring brand trust such as "The academic quality of the university never disappoints me" and three items measuring brand loyalty such as "If there was a lower tuition fee alternative in another university, I would still be in this university."

The citizenship behaviors were measured using two scales with three items each. In role behavior has been used in the literature to show the extent to which the consumer contributes to the effectiveness of the service they receive by providing information or by adhering to the established procedures. In our study we modified the scale used by Ho (2015) to be suitable for university students using items such as "I fully utilize the opportunities provided by this university with my hard work". Extra-role behavior has been used in the literature to show the extent to which customers are willing to go out of their way to provide positive word of mouth for the organization. Sample items are "I will recommend this university to my friends and relatives".

\subsection{Data analysis}

We used PLS for hypotheses testing and data analysis. PLS models are path models using indicators that make up latent variables in a similar way that is found in covariance based structural equation modeling. The PLS can show how each indicator varies in terms of its contribution to the composite score of the latent variable. PLS models make it possible to view some variables as effects of others while still be causes for variables later in the hypothesized causal sequence (Garson, 2016). PLS models are an alternative to covariance-based structural equation modeling. PLS path modeling has been popular in marketing, information systems and business research where the measurement model and the structural model factor loadings and path coefficients are of interest. Since PLS allows smaller sample sizes and does not make 
distributional assumption other than predictor specification (Chin, 2010), it was deemed appropriate for our study.

In our reporting of the results we use the two step approach that is commonly used with PLS analysis (Chin, 2010). First we focus on the reliability and the validity of the our measurement items to prove that they are representing the constructs that we have in our model. Subsequently, we focus on the structural model to see how well our hypothesized relationships are supported by our data.

\section{Results}

\subsection{Measurement model}

In line with previous studies using PLS (Ho, 2014, 2015; Kim, Fan, Chang, \& Park, 2016; Klarner, Sarstedt, Hoeck, \& Ringle, 2013) we established the reliability and the convergent validity as well as discriminant validity. Table 1 provides information on the reliability and convergent validity. Cronbach alpha values are shown to assess reliability. Composite reliability (CR), factor loadings, and average variance extracted (AVE) are provided to assess convergent validity. The Cronbach alpha values for the constructs are above the threshold value of 0.7 (Nunnally, 1978). The CR values ranged from 0.87 to 0.94 and AVE ranged from 0.70 to 0.85 which were well above 0.70 and 0.50 respectively which are the critical values recommended (Fornell \& Larcker, 1981).

Discriminant validity requires that the indicators should correlate weakly with the constructs other than the construct it belongs to. To assess discriminant validity, we examined the indicators' cross loadings to see if indicators had higher loadings on their own construct rather than other constructs. We also used Fornell and Larcker (1981) criterion, to see if each construct's AVE is higher than its correlation with all of the other constructs. Table 2 shows that square roots of AVEs are greater than the correlations between any two constructs. Our results indicate clearly that the constructs display discriminant validity.

Since our data collection relied on participants responding to the items it was necessary to check for single source bias or common method variance influence on the relationships in the PLS path model. We used Harman's single-factor test to check for common method bias by loading all the indicators or items in our study into an exploratory factor analysis (Sharma, Crawford, \& Yetton, 2009). A single factor or a general factor accounting for the majority of covariance among measures was not observed indicating common method bias was not a problem. 
Table 1: Measurement model evaluation results

\begin{tabular}{|c|c|c|c|c|c|}
\hline Construct & Measurement Items & Loading & $\alpha$ & CR & AVE \\
\hline \multirow[t]{3}{*}{$\begin{array}{l}\text { Strength of the University } \\
\text { Community on Facebook }\end{array}$} & $\begin{array}{l}\text { Share a common bond with other } \\
\text { followers }\end{array}$ & 0.943 & 0.899 & 0.936 & 0.831 \\
\hline & Are strongly affiliated with other members & 0.896 & & & \\
\hline & The followers benefit from this community & 0.895 & & & \\
\hline \multirow[t]{3}{*}{$\begin{array}{l}\text { Student Identification with } \\
\text { the University Community }\end{array}$} & $\begin{array}{l}\text { I see myself as a part of the university } \\
\text { community }\end{array}$ & 0.900 & 0.880 & 0.926 & 0.806 \\
\hline & $\begin{array}{l}\text { If this community planned something, I } \\
\text { would think it as something "we" would do } \\
\text { rather than something "they" would do. }\end{array}$ & 0.892 & & & \\
\hline & I am very attached to this community & 0.901 & & & \\
\hline \multirow[t]{3}{*}{$\begin{array}{l}\text { Student Identification with } \\
\text { the University Brand }\end{array}$} & $\begin{array}{l}\text { When someone compliments the } \\
\text { university, it feels like a personal } \\
\text { compliment }\end{array}$ & 0.900 & 0.852 & 0.910 & 0.772 \\
\hline & $\begin{array}{l}\text { When someone criticizes the university, it } \\
\text { feels like a personal insult }\end{array}$ & 0.906 & & & \\
\hline & $\begin{array}{l}\text { I am very interested in what others think } \\
\text { about this university }\end{array}$ & 0.829 & & & \\
\hline \multirow[t]{3}{*}{ University Brand Trust } & $\begin{array}{l}\text { Education that my university provides } \\
\text { fulfills my expectations }\end{array}$ & 0.928 & 0.909 & 0.943 & 0.847 \\
\hline & $\begin{array}{l}\text { I rely on the quality of education at the } \\
\text { university }\end{array}$ & 0.939 & & & \\
\hline & $\begin{array}{l}\text { The academic quality of the university } \\
\text { never disappoints me }\end{array}$ & 0.893 & & & \\
\hline \multirow[t]{3}{*}{ University Brand Loyalty } & $\begin{array}{l}\text { I consider myself to be loyal to the } \\
\text { university }\end{array}$ & 0.872 & 0.787 & 0.873 & 0.698 \\
\hline & $\begin{array}{l}\text { If there was a lower tuition fee alternative } \\
\text { in another university, I would still be in this } \\
\text { university }\end{array}$ & 0.886 & & & \\
\hline & $\begin{array}{l}\text { I am willing to pay more for a degree from } \\
\text { this university as opposed to a degree from } \\
\text { others }\end{array}$ & 0.740 & & & \\
\hline \multirow[t]{3}{*}{ Extra Role Behavior } & $\begin{array}{l}\text { I will recommend this university to my } \\
\text { friends and relatives }\end{array}$ & 0.893 & 0.891 & 0.932 & 0.821 \\
\hline & $\begin{array}{l}\text { I will tell my relatives and friends about the } \\
\text { good experience in this university }\end{array}$ & 0.936 & & & \\
\hline & $\begin{array}{l}\text { I am willing to join the activity hold by the } \\
\text { university in the future }\end{array}$ & 0.889 & & & \\
\hline \multirow[t]{3}{*}{ In Role Behavior } & $\begin{array}{l}\text { I fully utilize the opportunities provided by } \\
\text { the university with my hard work }\end{array}$ & 0.902 & 0.834 & 0.900 & 0.751 \\
\hline & $\begin{array}{l}\text { I may continue my further studies in this } \\
\text { university }\end{array}$ & 0.843 & & & \\
\hline & $\begin{array}{l}\text { Even if I had difficulties in my courses, I } \\
\text { would not consider leaving this university }\end{array}$ & 0.853 & & & \\
\hline
\end{tabular}


Table 2: Square root of AVE and Correlations between constructs

\begin{tabular}{lrrrrrrr}
\hline & 1 & 2 & 3 & 4 & 5 & 6 & 7 \\
\hline 1. Strength of Univ. Facebook & $\mathbf{0 . 9 1 1}$ & & & & & & \\
Community & & & & & & & \\
2. Identify with Community & 0.593 & $\mathbf{0 . 8 9 8}$ & & & & & \\
3. Identify with Univ. Brand & 0.474 & 0.593 & $\mathbf{0 . 8 7 9}$ & & & & \\
4. Univ. Brand Trust & 0.509 & 0.681 & 0.64 & $\mathbf{0 . 9 2}$ & & & \\
5. Univ. Brand Loyalty & 0.527 & 0.643 & 0.6 & 0.697 & $\mathbf{0 . 8 3 6}$ & & \\
6. In Role & 0.527 & 0.638 & 0.59 & 0.714 & 0.73 & $\mathbf{0 . 8 6 7}$ & \\
7. Extra Role & 0.53 & 0.711 & 0.639 & 0.764 & 0.723 & 0.79 & $\mathbf{0 . 9 0 6}$ \\
\hline
\end{tabular}

Note: Square roots of AVE are provided in the diagonal, the other values are correlation coefficients

\subsection{Structural model}

Figure 2 shows the result of the PLS structural model with the path coefficients and the R square values indicating to what extent the variance in the dependent variable was explained by the independent variables. Loyalty explained $53.2 \%$ of the variance in in-role behaviors and $52.3 \%$ of the variance in Extra-role behavior of the participants in our study. The model of explains $55.9 \%$ of the variance in Loyalty. Identification with the university community and the university brand explain $55 \%$ of the variation in Trust. And the perceived strength of the Facebook community explains $35.2 \%$ and $37.4 \%$ of the variation in student identification with the university community and university brand respectively.

Table 3 provides the t-values and the significance levels for the path coefficients which were calculated using bootstrapping with 1000 resamples. Hypotheses 1 and 2 argued that the perceived strength of the university Facebook community will enhance the identification with the university community and identification with the university brand. The path coefficients were $\beta=0.593, p<0.001$ and $\beta=0.187, p=0.068$, not significant supporting $\mathrm{H} 1$ but not $\mathrm{H} 2$.

Hypothesis 3 and Hypothesis 4 expected that trust is related to the level of identification with the University community and the university brand. Our results show $\beta=0.465, \mathrm{p}<0.001$ and $\beta$ $=0.365, \mathrm{p}<0.001$ respectively. Hypothesis 5 stated that trust and loyalty are related and the results show the path coefficient as $\beta=0.395$. Hypothesis 6 and Hypothesis 7 state that loyalty will lead to ices in role and extra role behaviors. This was supported with $\beta=0.73, p<0.001$ for in role and $\beta=0.723, \mathrm{p}<0.001$ for extra role behaviors.

We also investigated whether the relationship between perceived strength of the Facebook community and student identification with the university brand is mediated by the student identification with the university community. We found that the direct effect of perceived strength of the Facebook community (independent variable) on student identification with the university brand (dependent variable) is $\beta=0.187, \mathrm{p}=0.068$, ns, however the indirect effect through student identification with the university community (mediator) is $\beta=0.286, p<0.001$. This means that there is full mediation of student identification with the university community on the relationship between Facebook community and brand identification. In other words, we can 
argue that the reason that Facebook community has an influence on brand identification is due to the increased university community identification. We can recommend that universities should strive to enhance community identification.

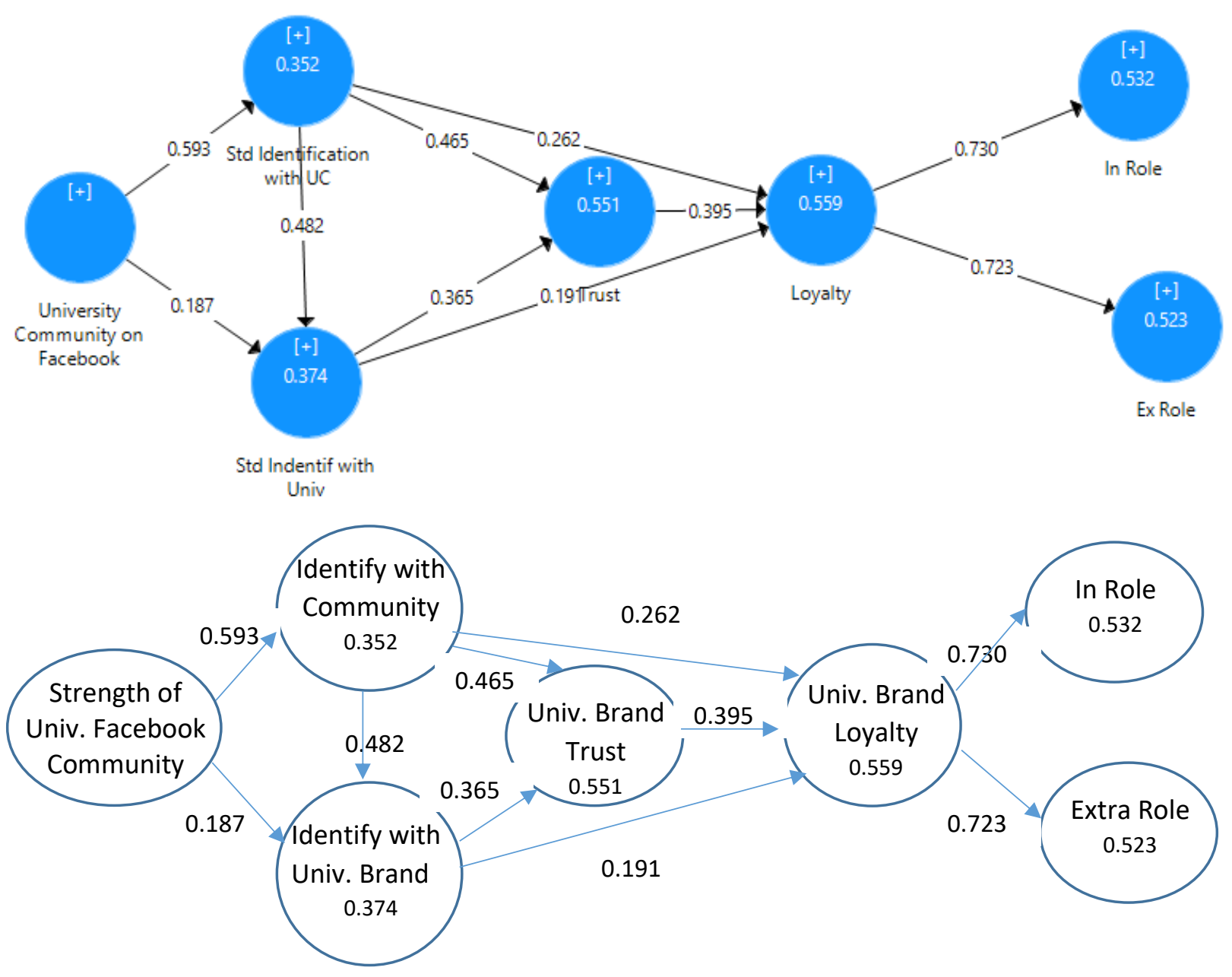

Figure 2: Structural Model Analysis

The role of trust as a mediator was also investigated. We checked to see if student identification with the university community and the loyalty relationship is mediated by trust. We see that the direct effect between student identification with the university community and loyalty is $\beta=0.262, p<0.001$, and the indirect effect that goes from student identification with the university community and mediated by trust is $\beta=(0.465 \times 0.395)=0.183, \mathrm{p}<0.01$. This indicates that there is a partial mediation. We also checked whether student identification with the university brand and loyalty relationship is mediated by trust. The results show a direct relationship between identification with brand and loyalty of $\beta=0.191, \mathrm{p}<0.01$. The mediated indirect path is $\beta=0.365 \mathrm{x}$ 
$0.395=0.144, \mathrm{p}<0.01$. The results indicate that the reason that identification with university community and university brand results in higher loyalty is due to the increased trust.

Table 3: Hypotheses testing

\begin{tabular}{|c|c|c|c|c|}
\hline Hypothesis & & Coefficient & T-Value & Supported \\
\hline $\mathrm{H} 1$ & Strength of Univ. Facebook Community -> Identify with Community & $0.593 * * *$ & 9.265 & Yes \\
\hline $\mathrm{H} 2$ & Strength of Univ. Facebook Community -> Identify with Univ. Brand & 0.187 & 1.767 & No \\
\hline H3 & Identify with Community -> Trust & $0.465^{* * *}$ & 5.859 & Yes \\
\hline $\mathrm{H} 4$ & Identify with Univ. Brand -> Trust & $0.365^{* * *}$ & 4.492 & Yes \\
\hline H5 & Univ. Brand Trust -> Univ. Brand Loyalty & $0.395 * * *$ & 5.062 & Yes \\
\hline H6 & Loyalty $->$ In Role & $0.73 * * *$ & 15.802 & Yes \\
\hline $\mathrm{H} 7$ & Loyalty -> Ex Role & $0.723 * * *$ & 14.467 & Yes \\
\hline
\end{tabular}

Note:

${ }^{*} p<0.05 * * p<0.01, * * * p<0.001$

\section{Discussion and conclusion}

The study has sought to test how the perceived strength of the Facebook community of a university by the users is related to the users' identification with the university community and the university brand. The role of identification with the university community and the brand on increasing brand trust and loyalty was also examined. Finally, the impact of loyalty on in role and extra role behaviors such as being an active part of the learning process in the university and acting as an advocate for the university was explored.

Our results reveal that the perceived strength of the Facebook community of the university influences the student identification with the university community which in turn leads to student identification with the university brand. We find a full mediating effect of student identification with the university community on the relationship between the perceived strength of the university Facebook community and student identification with the university brand. In other words, the reason that the strong Facebook community can result in strong identification with the brand is because of the role of identification with the university community. Universities need to enhance the identification with the university community. One way is through a stronger social media presence, but universities should also consider other tools that will strengthen the engagement of the student in the university community.

The mediating role of trust between identification and loyalty show that the at least part of the reason that students who have higher identification with the university have higher loyalty is due to the higher level of trust that they develop. This means that universities need to find ways to increase levels of trust. One way as this article demonstrates is by increasing the identification with the community and with the brand. Universities need to also seek additional ways of increasing this level of trust through other mechanisms such as being truthful in their promises and outcomes that they are able to deliver. 
The identification is not only present on the main Facebook page of the university, but also on other departmental or unit pages that university members follow. For instance, the International Center Facebook page of the university is a more specific target page for international students, as there is a present community on the page with same shared intentions and queries.

Another aspect of identification occurs when alumni of the university finds a platform to share their memories and loyalty to the university. At the beginning of 2015, the graduates of the university had created a Facebook group with a slogan "Our goal is to come together again" in order to form a community to share memories, photographs and student life. It raised high interest among students and within few days the group had more than 25,000 members. The group became a symbol for the university identification as each member, through comments and shares, explored what it meant to be a member of the university for them, back then and now.

When students and their families are to make decisions about which university to choose for higher education, they are not able to make sense of the complex and detailed issues ranging from quality of the faculty and the physical resources to employability of graduates and thus rely on the brand to simplify this decision (Judson et al., 2008). Judson (2008) suggested that the brand strength of a university is dependent on how distinctive the university's brand is perceived to be, and the clarity of the branding message, how involved the university is in the promotion of the brand and the university's brand image. Similarly, employers also rely on the brand to assess the job seekers that have degrees from the rapidly growing number of universities and academic programs, since it would be too costly for them to attempt to evaluate quality of the educational outcomes of the large number of universities. An effective social media presence including university Facebook pages will assist to develop a stronger university brand community which will facilitate the identification with the university community and the university brand. The Facebook community will allow the university to clearly express the distinctiveness of its brand. If used effectively the reach of the message can be tremendously higher compared to traditional media. The university community members can share the posts of the university to their contacts, friends or followers which will extend the reach of the message. The community will only share the messages or posts if it is interesting enough and if they are willing to use their reputation to be associated with it. They may not wish to share material that is uninteresting for their followers or that they personally are not confident to endorse.

Previous research on international university students studying in North Cyprus had revealed that although students did not report dissatisfaction, the majority of students had indicated that they would transfer to another university abroad if given the chance (Mehtap-Smadi \& Hashemipour, 2011). Our model demonstrates that loyalty is influenced by trust and trust can be improved by increasing the student identification with the university. A stronger presence in social media will strengthen the identification with the community and the university brand.

Our study investigated the how the university community on the social media may influence the behavior of the university students. The study setting resulted in a large number of international students who were studying in a location away from their home country. Perhaps the results may differ if the study is conducted in a different context on students who are more homogenous or from the local community. A large proportion of our respondents were male. While this also reflects the larger ratio of male students studying in the university where the study was 
conducted, it may have an influence on our findings. Another limitation may be the use of an online survey, which resulted in a low response rate (Barreda, Bilgihan, Nusair, \& Okumus, 2015). We recommend that future research include respondents from a variety of higher education institutions where the differing levels of university reputation can also be a factor in the model.

\section{References}

Ahearne, M., Bhattacharya, C. B., \& Gruen, T. (2005). Antecedents and Consequences of CustomerCompany Identification: Expanding the Role of Relationship Marketing. Journal of Applied Psychology, 90(3), 574-585. doi:10.1037/0021-9010.90.3.574

Algesheimer, R., Dholakia, U. M., \& Herrmann, A. (2005). The Social Influence of Brand Community: Evidence from European Car Clubs. Journal of Marketing, 69(3), 19-34. doi:10.1509/jmkg.69.3.19.66363

Alkhas, A. B. (2011). An Examination of Internet Social Media Marketing In Higher Educaion Institutions. California State University, Stanislaus.

Arnett, D. B., German, S. D., \& Hunt, S. D. (2003). The Identity Salience Model of Relationship Marketing Success: The Case of Nonprofit Marketing. Journal of Marketing, 67(2), 89-105. doi:10.1509/jmkg.67.2.89.18614

Arnett, J. J. (2015). How digital natives spend their time. Oxford University Press's Academic Insights for the Thinking World. Retrieved May 6, 2016, from http://blog.oup.com/2015/03/digital-nativesemerging-adulthood-infographic/\#sthash.AMjsS5dk.dpuf

Ashforth, B. E., \& Mael, F. (1989a). Social Identity Theory and the Organization. Academy of Management Review, 14(1), 20-39. doi:10.5465/AMR.1989.4278999

Ashforth, B. E., \& Mael, F. (1989b). Social Identity Theory and the Organization. Academy of Management Review, 14(1), 20-39. doi:10.5465/AMR.1989.4278999

Bagozzi, R. P., Fazio, R. H., \& Williams, C. J. (1992). The Self-Regulation of Attitudes, Intentions, and Behavior. Social Psychology Quarterly, 55(2), 178-204. doi:10.2307/2786945

Bagozzi, R. P., Gopinath, M., \& Nyer, P. U. (1999). The Role of Emotions in Marketing. Journal of the Academy of Marketing Science, 27(2), 184-206. doi:10.1177/0092070399272005

Bateman, T. S., \& Organ, D. W. (1983). Job Satisfaction and the Good Soldier: The Relationship Between Affect and Employee "Citizenship". Academy of Management Journal, 26(4), 587-595. doi:10.2307/255908

Becker, R., \& Kolster, R. (2012). International Student Recruitment: Policies and Developments in Selected Countries. The Hague, The Netherlands. Retrieved from https://www.epnuffic.nl/en/publications/find-a-publication/international-student-recruitment.pdf

Bergami, M., \& Bagozzi, R. P. (2000). Self-categorization, affective commitment and group self-esteem as distinct aspects of social identity in the organization. British Journal of Social Psychology, 39(4), 
555-577. doi:10.1348/014466600164633

Bove, L. L., Pervan, S. J., Beatty, S. E., \& Shiu, E. (2009). Service worker role in encouraging customer organizational citizenship behaviors. Journal of Business Research, 62(7), 698-705. doi:10.1016/j.jbusres.2008.07.003

Chaudhuri, A., \& Holbrook, M. B. (2001). The Chain of Effects from Brand Trust and Brand Affect to Brand Performance: The Role of Brand Loyalty. Journal of Marketing, 65(2), 81-93. doi:10.1509/jmkg.65.2.81.18255

Chin, W. W. (2010). How to Write Up and Report PLS Analyses. In V. Esposito Vinzi, W. W. Chin, J. Henseler, \& H. Wang (Eds.), Handbook of Partial Least Squares. Berlin, Heidelberg: Springer Berlin Heidelberg. doi:10.1007/978-3-540-32827-8

Delgado-Ballester, E., \& Luis Munuera-Alemán, J. (2001). Brand trust in the context of consumer loyalty. European Journal of Marketing, 35(11/12), 1238-1258. doi:10.1108/EUM0000000006475

Fornell, C., \& Larcker, D. F. (1981). Evaluating structural equation models with unobservable variables and measurement error. Journal of Marketing Research (JMR), 18(1).

Garson, G. D. (2016). Partial Least Squares: Regression \& Structural Equation Models.

Groth, M. (2005). Customers as Good Soldiers: Examining Citizenship Behaviors in Internet Service Deliveries. Journal of Management, 31(1), 7-27. doi:10.1177/0149206304271375

Halbesleben, J. R. B., \& Wheeler, A. R. (2009). Student Identification With Business Education Models: Measurement and Relationship to Educational Outcomes. Journal of Management Education, 33(2), 166-195. doi:10.1177/1052562908320658

Ho, C.-W. (2014). Consumer behavior on Facebook. EuroMed Journal of Business, 9(3), 252-267. doi:10.1108/EMJB-12-2013-0057

Ho, C.-W. (2015). Identify with community or company? An investigation on the consumer behavior in Facebook brand community. Telematics and Informatics, 32(4), 930-939. doi:10.1016/j.tele.2015.05.002

Jones, C., Ramanau, R., Cross, S., \& Healing, G. (2010). Net generation or Digital Natives: Is there a distinct new generation entering university? Computers \& Education, 54(3), 722-732. doi:10.1016/j.compedu.2009.09.022

Judson, K. M., Aurand, T. W., Gorchels, L., \& Gordon, G. L. (2008). Building a University Brand from Within: University Administrators' Perspectives of Internal Branding. Services Marketing Quarterly, 30(1), 54-68. doi:10.1080/15332960802467722

Kim, M., Fan, S., Chang, Y., \& Park, J. (2016). Determinants of customer loyalty in the Korean smartphone market : Moderating effects of usage characteristics. Telematics and Informatics, 33(4), 936-949. doi:10.1016/j.tele.2016.02.006

Klarner, P., Sarstedt, M., Hoeck, M., \& Ringle, C. M. (2013). Disentangling the effects of team competences, team adaptability, and client communication on the performance of management consulting teams. Long Range Planning, 46(3), 258-286. doi:10.1016/j.Irp.2013.03.001

Laroche, M., Habibi, M. R., \& Richard, M. O. (2013). To be or not to be in social media: How brand loyalty is affected by social media? International Journal of Information Management, 33(1), 76-82. 
doi:10.1016/j.ijinfomgt.2012.07.003

Laroche, M., Habibi, M. R., Richard, M.-O., \& Sankaranarayanan, R. (2012). The effects of social media based brand communities on brand community markers, value creation practices, brand trust and brand loyalty. Computers in Human Behavior, 28(5), 1755-1767. doi:10.1016/j.chb.2012.04.016

Lin, J. (2008). Research shows that Internet is rewiring our brains. UCLA Today. Retrieved May 6, 2016, from http://newsroom.ucla.edu/stories/081015_gary-small-ibrain

McAlexander, J. H., Koenig, H. F., \& John W. Schouten. (2005). Building a University Brand Community: The Long- Term Impact of Shared Experiences. Journal of Marketing for Higher Education, 14(2), 61-79. doi:10.1300/J050v14n02

McAlexander, J. H., Koenig, H. F., \& Padilla, A. (2006). Building Relationships of Brand Community in Higher Education: A Strategic Framework for University Advancement. International Journal of Educational Advancement, 6(2), 107-118. doi:10.1057/palgrave.ijea.2150015

McAlexander, J. H., Koenig, H. F., \& Schouten, J. W. (2005). Building a University Brand Community: The Long-Term Impact of Shared Experiences. Journal of Marketing for Higher Education, 14(2), 61-79. doi:10.1300/J050v14n02_04

Mehtap-Smadi, S., \& Hashemipour, M. (2011). In Pursuit of an International Education Destination Reflections From a University in a Small Island State. Journal of Studies in International Education, 15(5), 409-428. doi:10.1177/1028315310365539

Nunnally, J. C. (1978). Psychometric Theory McGraw-Hill. New York.

Prensky, M. (2001). Digital Natives, Digital Immigrants Part 1. On the Horizon, 9(5), 1-6. doi:10.1108/10748120110424816

Prensky, M. (2005, December). Listen to the natives. Educational Leadership, 8-13. Retrieved from http://www.ascd.org/ASCD/pdf/journals/ed_lead/el200512_prensky.pdf

Rosenbaum, M. S., \& Massiah, C. A. (2007). When Customers Receive Support From Other Customers: Exploring the Influence of Intercustomer Social Support on Customer Voluntary Performance. Journal of Service Research, 9(3), 257-270. doi:10.1177/1094670506295851

Scott, S. G., \& Lane, V. R. (2000). A STAKEHOLDER APPROACH TO ORGANIZATIONAL IDENTITY. Academy of Management Review, 25(1), 43-62. doi:10.5465/AMR.2000.2791602

Sharma, P., Crawford, J., \& Yetton, P. (2009). Estimating the effect of common method variance: The method-method pair technique with an illustration from TAM research. MIS Quarterly, 33(3), 1-13. doi:Article

Srinivasan, S. S., Anderson, R., \& Ponnavolu, K. (2002). Customer loyalty in e-commerce: An exploration of its antecedents and consequences. Journal of Retailing, 78(1), 41-50. doi:10.1016/S00224359(01)00065-3

Varghese, N. V. (2008). Globalization of Higher Education and Cross-Border Student Mobility. Paris. Retrieved from http://www.unesco.org/iiep/PDF/pubs/2008/Globalization_HE.pdf

Vey, M. A., \& Campbell, J. P. (2004). In-Role or Extra-Role Organizational Citizenship Behavior: Which Are We Measuring? Human Performance, 17(1), 119-135. doi:10.1207/S15327043HUP1701_6 
Webometrics: Ranking Web of Universities. (2016). Retrieved from http://www.webometrics.info/en Center for Community College Student Engagement (CCCSE). (2009). Making connections: Dimensions of student engagement (2009 CCSSE Findings). Austin, TX: The University of Texas at Austin, Community College Leadership Program. 